Katarzyna Mikołajczyk*

\title{
WPŁYW WIELKOŚCI BANKU NA JEGO EFEKTYWNOŚĆ: BADANIA DLA KRAJÓW EUROPY ŚRODKOWO-WSCHODNIEJ
}

\section{Wprowadzenie}

Ostatni kryzys finansowy, w którym szczególną rolę odegrały duże banki o złożonej strukturze organizacyjnej, silnych i rozległych powiązaniach finansowych i szerokim geograficznym zasięgu działania, spowodował ożywienie dyskusji dotyczącej optymalnej wielkości instytucji kredytowych, zarówno z punktu widzenia wartości pojedynczego banku, jak i bezpieczeństwa oraz stabilności całego sektora finansowego. Nowe regulacje nakierowane na wzmocnienie kapitałowe banków, szczególnie tych zidentyfikowanych jako instytucje systemowo ważne, spowodowały odwrót dotychczasowych tendencji polegających na dążeniu do szybkiego wzrostu aktywów, głównie w wyniku fuzji i przejęć oraz zastąpienie go falą dezinwestycji podjętych w największych bankach. Ważnym elementem podkreślanym w dyskusjach na temat wielkości banku jest zróżnicowany model jego funkcjonowania: małe banki utrzymują model relacyjny, podczas gdy duże banki odeszły od modelu relacyjnego na rzecz transakcyjnego.

Specyfiką sektora bankowego w krajach Europy Środkowo-Wschodniej (ESW) jest bardzo wysoki udział kapitału zagranicznego. Większość banków środkowoeuropejskich jest spółkami córkami banków z Europy Zachodniej, które w dużym stopniu wpływają na ich model biznesowy i strategię działania. Funkcjonowanie w ramach grupy kapitałowej jest zarówno źródłem korzyści (wewnętrzny rynek kapitałowy, przepływ informacji, wsparcie technologiczne), jak i ograniczeń (przesuwanie środków do najbardziej rentownych podmiotów, uzależnienie aktywności w spółkach zależnych od sytuacji finansowej spółek matek), nie pozostaje też bez wpływu na kwestię optymalnej skali działania. Banki ESW w ujęciu absolutnym (wartość aktywów) są relatywnie małe: w 2013 r. aktywa największego polskiego

* Uniwersytet Ekonomiczny w Krakowie, Wydział Finansów. 
banku PKO BP stanowiły zaledwie 2,5\% aktywów największego europejskiego banku, $\mathrm{HSBC}^{1}$. W analizach uwzględniających wielkość banku równie istotne jest jednak ujęcie względne, odzwierciedlające udział aktywów pojedynczego banku w aktywach krajowego sektora bankowego bądź relację wartości jego aktywów do krajowego PKB. Duże i średnie banki w krajach ESW mają zazwyczaj charakter banków uniwersalnych, łącząc aktywność w różnych segmentach bankowości ze zróżnicowanymi źródłami ich finansowania. Małe banki zwykle budują swoją pozycję rynkową w wybranej niszy, oferując swoim klientom znacznie węższy zakres wyspecjalizowanych produktów. Mogą specjalizować się np. w kredytach i pożyczkach konsumpcyjnych, kredytach samochodowych czy bankowości korporacyjnej. Małe banki wykazują też znacznie większe zróżnicowanie własnościowe: są wśród nich zarówno banki w 100\% należące do banków zagranicznych, jak i banki z kapitałem krajowym, zarówno komercyjne jak i spółdzielcze, a także banki kontrolowane przez fundusze private equity.

Celem niniejszego artykułu jest analiza wpływu skali działania banków w ESW na ich efektywność. W tym celu banki podzielono na grupy odzwierciedlające ich wielkość (absolutną, mierzoną wartością aktywów i względną, mierzoną ich udziałem w aktywach krajowego sektora bankowego) i dla wyróżnionych grup porównano wskaźniki efektywności, zarówno technicznej jak i efektywności skali. Wskaźniki efektywności wyliczono, wykorzystując nieparametryczną metodę DEA, a jako okres badawczy przyjęto lata 2004-2013.

\section{Koszty i korzyści wynikające ze skali działania banku - przegląd literatury}

Pytanie o optymalną wielkość banku oraz analiza wpływu skali działania banku na jego strategię, efektywność, rentowność i stabilność są tematem często podejmowanym w literaturze przedmiotu, zarówno w ujęciu teoretycznym jak i empirycznym, jednak wnioski wyciągane na podstawie tych badań nie są jednoznaczne. Szczególnie bogate są badania dotyczące amerykańskich banków lokalnych, ich strategii działania i efektywności w zależności od charakteru lokalnego rynku, jego konkurencyjności, obecności dużych banków na rynku lokalnym czy rodzaju powiązań z klientami²,

\footnotetext{
1 Top 1000 world banks, “The Banker” lipiec 2014. Bank PKO BP był także największym bankiem regionu ESW, z wyłączeniem Rosji.

2 Zob. R. DeYoung, W.C. Hunter i G.F. Udell, Past, present, and probable future for community banks: Evidence from a degree of total leverage model, "Journal of Financial Intermediation" 2001, No. 10; A.N. Berger,
} 
a ogólne konkluzje są $\mathrm{w}$ dużym stopniu zgodne $\mathrm{z}$ badaniami na rynku europejskim. Tradycyjnie jako elementy przewagi małych banków wskazuje się dobrą znajomość lokalnego rynku i silne, długoterminowe relacje z klientami, wzmacniające ich lojalność wobec banku. Wieloletnia współpraca z klientami stanowi źródło „miękkich informacji” pozwalających właściwie ocenić ich zdolność kredytową i w efekcie podtrzymać finansowanie, w sytuacji gdy napotykają oni kłopoty o charakterze przejściowym. Zindywidualizowane podejście do klienta i wykorzystanie informacji wybiegających poza standardowe procedury stosowane w dużych bankach jest też istotnym czynnikiem wpływającym na ich ważną rolę w finansowaniu firm o krótkim okresie funkcjonowania. Jako obszary, w których małe banki wykazują przewagę wobec banków dużych wskazuje się głównie obsługę gospodarstw domowych oraz małych i średnich przedsiębiorstw³ ${ }^{3}$. Jednakże zmiany technologiczne i dostęp do baz danych, pozwalające na zastosowanie modeli credit scoring do oceny zdolności kredytowej klientów detalicznych oraz małych przedsiębiorstw spowodowały, że lokalne banki w coraz większym stopniu tracą przewagę konkurencyjną w tych obszarach. Jest to szczególnie widoczne w odniesieniu do standaryzowanych produktów, niewymagających personalnych relacji pomiędzy bankiem i klientem ${ }^{4}$. Teza o utracie przez małe banki przewagi konkurencyjnej w zakresie kredytowania małych i średnich przedsiębiorstw, w wyniku postępu technologicznego i deregulacji, jest coraz częściej pozytywnie weryfikowana w badaniach empirycznych ${ }^{5}$.

Innym źródłem przewagi konkurencyjnej małych banków może być ich prostsza struktura organizacyjna, co redukuje problem asymetrii informacji i zmniejsza koszty monitorowania pracowników, tak aby zapobiec podejmowaniu przez nich decyzji niezgodnych $\mathrm{z}$ interesem banku. W wypadku dużych banków następuje też znacznie szybsza rotacja pracowników, przesunięcia pomiędzy różnymi stanowiskami i oddziałami, co nie sprzyja budowaniu relacji i prowadzi do utraty „miękkich” informacji ${ }^{6}$. Z drugiej jednak strony małym bankom trudno podołać wciąż nowym wyzwaniom technologicznym, a wysokie koszty stałe są źródłem nieefektywności skali. Małe banki próbujące zwiększyć skalę działania poprzez ekspansję i dywersyfikację działalności często jednak płacą za to redukcją rentowności, gdyż

W. Goulding, T. Rice, Do small business still prefer community banks?, "Journal of Banking and Finance" 2014, No. 44.

3 Zob. S. Mercieca, K. Schaeck, S. Wolfe, Small European banks: Benefits from diversification?, "Journal of Banking and Finance" 2007, No. 31.

4 D.A. Carter, J.E. McNulty, Deregulation, technological change, and the business-lending performance of large and small banks, "Journal of Banking and Finance" 2005, No. 29.

5 A.N. Berger, W. Goulding, T. Rice, op.cit.

6 D.A. Carter, J.E. McNulty, op.cit. 
wchodzą w nowe obszary biznesowe, w których nie są w stanie podołać konkurencji ze strony dużych banków?

W porównaniach banków o różnej wielkości zwraca się też uwagę na kwestię stabilności osiąganych przez nie wyników (mierzonych najczęściej rentownością lub wartością rynkową). Duże banki wykazują zwykle większą skłonność do podejmowania ryzyka, co wpływa destabilizująco na ich wyniki. $Z$ drugiej jednak strony duże banki mają też możliwość większej dywersyfikacji działania, wyrażonej zarówno poprzez szerszy wachlarz produktów i usług, jak i znacznie rozleglejszy obszar geograficzny, a także mają łatwiejszy dostęp do kapitału. Dywersyfikacja produktowa w małych bankach zwykle nie jest korzystna, gdyż towarzyszy jej wzrost złożoności podejmowanych działań, a koszty z tym związane przekraczają potencjalne korzyści wynikające z redukcji poziomu ryzyka ${ }^{8}$. Dla małych banków bardziej korzystna jest zwykle silna specjalizacja w wybranej niszy rynkowej, gdzie zindywidualizowany charakter produktów pozwala im uzyskać wyższe marże, pozwalające pokryć wyższe jednostkowe koszty działania.

T.H. Hannan i R.A. Prager, badając wpływ pojawienia się konkurencji ze strony dużego banku na rentowność i efektywność lokalnych banków w Stanach Zjednoczonych, zauważyli, że rywalizacja taka często pozwala małym bankom zwiększyć rentowność przez obniżenie kosztów pozyskania kapitału, gdyż duże, międzynarodowe banki oferują zwykle niskie stopy oprocentowania depozytów. Jednakże równocześnie duże banki, mające lepszy dostęp do finansowania z rynku międzybankowego, mogą zaoferować bardziej korzystne warunki kredytowania (szczególnie dla klientów o wysokiej zdolności kredytowej) oraz szerszy wachlarz produktów i usług, odbierając klientów małym bankom ${ }^{9}$. Wnioski z badań empirycznych dotyczących wpływu wielkości banku na stabilność ich wyników są bardzo zróżnicowane, uzależnione zarówno od przyjętej metody, jak i okresu badawczego oraz zasięgu geograficznego. We wcześniejszych analizach, obejmujących dane sprzed 2005 r., często nie wykazywano statystycznie istotnej relacji pomiędzy wielkością banku a jego bezpieczeństwem ${ }^{10}$ lub też wykazywano, że małe banki są bardziej ryzykowne (dodatnia relacja między wielkością a wskaźnikiem Z-score), jednak bardziej aktualne badania

\footnotetext{
7 S. Mercieca et al., op.cit.

8 O. De Jonghe, M. Diepstraten, G. Schepens, Banks' size, scope and systemic risk: What role for conflicts of interest?, "Journal of Banking and Finance" 2015.

9 T.H. Hannan, R.A. Prager, The profitability of small single-market banks in an era of multi-market banking, "Journal of Banking and Finance" 2009, No. 33.

$10 \mathrm{~W}$ badaniach empirycznych jako wskaźnik ryzyka często przyjmuje się Z-score, uwzględniający poziom i zmienność rentowności aktywów, a także stopień kapitalizacji banku. Odzwierciedla on odległość banku od bankructwa (mierzoną liczbą odchyleń standardowych ROA), czyli wyższy poziom wskaźnika Z-score oznacza wyższy poziom bezpieczeństwa.
} 
coraz częściej pozwalają wyciągnąć przeciwne wnioski: zwiększenie skali działania banku powoduje wzrost zmienności wyników oraz mniejszą stabilność i bezpieczeństwo $^{11}$. J. de Haan i T. Poghosyan, analizując powyższy problem, zwrócili jednak uwagę na nieliniowość tej relacji: wzrost wielkości banku sprzyja jego stabilności (obniża zmienność wyników), ale tylko do pewnego limitu wielkości, przekroczenie limitu 5 mld USD powoduje bowiem odwrócenie tej zależności (limit określono dla próby amerykańskich banków, a jego poziom uległ obniżeniu po ostatnim kryzysie (inansowym $)^{12}$.

Stabilność i bezpieczeństwo pojedynczego banku są także bardzo istotne z punktu widzenia makroekonomicznego: bezpieczeństwa całego systemu bankowego oraz stabilności finansowania sektora niefinansowego. Wielkość banku (obok innych czynników, odzwierciedlających głównie strukturę własnościową, model biznesowy i źródła finansowania, które także są silnie uwarunkowane skalą działania banku) okazała się istotnym czynnikiem wyjaśniającym odporność banków na ostatni kryzys finansowy: małe banki są zwykle wskazywane jako te, które dzięki bardziej zindywidualizowanemu i długoterminowemu podejściu do klienta, stanowiącemu rdzeń reprezentowanego przez nie modelu bankowości relacyjnej, wykazały większą zdolność do podtrzymania kredytowania w okresie niesprzyjających warunków makroekonomicznych ${ }^{13}$.

\section{Opis danych i metody badawczej}

W części empirycznej artykułu dokonano analizy porównawczej banków o różnej wielkości, przy czym uwzględniono zarówno ich wielkość absolutną, mierzoną sumą aktywów, jak i wielkość względną, mierzoną udziałem banku w aktywach krajowego sektora bankowego. Wielkość relatywna, odzwierciedlająca siłę rynkową banku, jest bardzo istotnym czynnikiem, który coraz częściej uwzględnia się, obok wielkości absolutnej, zarówno w badaniach w skali mikro (model biznesowy, efektywność,

11 Zob. K.J. Stiroh, Diversification in banking: is non-interest income the answer?, "Journal of Money, Credit and Banking” 2004, No. 36; S. Mercieca, K. Schaeck, S. Wolfe, op.cit.; A.C. Bertay, A. Demirgü-Kunt, H. Huizinga, Do we need big banks? Evidence on performance, strategy and market discipline, "Journal of Financial Intermediation" 2013, No. 22; R. Barrel, E.P. Davis, T. Fic, D. Karim, The future of financial regulation - Is there a link from bank size to risk?, "NIESR Discussion Paper” 2011, No. 367.

12 J. De Haan, T. Poghosyan, Size and earnings volatility of US bank holding companies, "Journal of Banking and Finance" 2012, No. 36.

${ }^{13} \mathrm{~F}$. Vallascas, K. Keasey, Bank resilience to systemic shocks and the stability of banking systems: Small is beautiful, "Journal of International Money and Finance" 2012, No. 31. 
profil ryzyka), jak i w skali makro (stabilność sektora bankowego, oddziaływanie antycykliczne). Wprowadzenie podziału według wielkości względnej wynika też z faktu, że badaniami objęto banki z kilkunastu krajów, o zróżnicowanym potencjale ekonomicznym. W badaniach międzynarodowych wprowadzenie ujednoliconych granic dla klas opartych na wielkości absolutnej może zniekształcić obraz, powodując, że duże banki (w kategoriach krajowych), nawet te posiadające dominującą pozycję rynkową, jednak pochodzące z małych krajów, zaliczane są do grup banków średnich i małych, a mniejsze banki z dużych krajów zaliczane są do wyższych grup. Ponadto równoczesna analiza wpływu wielkości banku, wyrażonej w ujęciu absolutnym i względnym, na jego efektywność pozwoli ocenić, która z tych charakterystyk $\mathrm{w}$ większym stopniu odpowiada za jej zróżnicowanie.

W obu klasyfikacjach banki podzielono na cztery grupy, a dokładne kryteria podziału przedstawiono $\mathrm{w}$ tabeli 1 .

Tabela 1. Kryteria podziału banków na grupy odzwierciedlające ich wielkość

\begin{tabular}{|l|l|c|c|l|}
\hline \multicolumn{1}{|c|}{ Kryterium podziału na grupy } & \multicolumn{1}{|c|}{ DUŻE } & \multicolumn{1}{c|}{ ŚREDNIE } & \multicolumn{1}{c|}{ MALE } & BARDZO MALE \\
\hline Wielkość absolutna: suma aktywów banku & $\begin{array}{l}\text { powyżej } \\
5 \text { mld EUR }\end{array}$ & $\begin{array}{l}\text { od 1 mld EUR } \\
\text { do } 5 \text { mld EUR }\end{array}$ & $\begin{array}{l}\text { od } 300 \text { tys. EUR } \\
\text { do } 1 \text { mld EUR }\end{array}$ & $\begin{array}{l}\text { poniżej } \\
300 \text { tys. EUR }\end{array}$ \\
\hline $\begin{array}{l}\text { Wielkość względna: udział banku w krajowym } \\
\text { rynku bankowym (mierzony aktywami) }\end{array}$ & powyżej 5\% & od 2\% do 5\% & od $1 \%$ do $2 \%$ & poniżej 1\% \\
\hline
\end{tabular}

Źródło: Opracowanie własne.

Badaniami objęto banki komercyjne z 11 krajów Europy Środkowo-Wschodniej, będących członkami Unii Europejskiej. Przyjęto 10-letni okres badawczy 2004-2013, w którym można wyróżnić trzy podokresy: okres boomu kredytowego (2004-2007), kryzysu finansowego (2008-2010) i okres pokryzysowy (2011-2013). W badaniach wykorzystano dane jednostkowe ze sprawozdań finansowych banków pochodzące z bazy danych Bankscope. Liczebność zbioru badawczego wynosiła ok. 200 banków, jednak była zróżnicowana w poszczególnych latach (najmniej banków było w $2004 \mathrm{r}$. - 174, najwięcej w 2011 r. - 218).

W celu weryfikacji sformułowanej tezy badawczej o wpływie wielkości banku na jego efektywność, zastosowano nieparametryczną metodę Data Envelopment Analysis (DEA). DEA należy do metod z zakresu programowania liniowego, która dla analizowanego zbioru jednostek identyfikuje relatywną granicę ich efektywności, a następnie ustala wskaźniki efektywności, przyjmujące wartości od 0 do 1 , odzwierciedlające odległość od tej granicy (wskaźnik równy 1 oznacza pełną efektywność procesu przekształcania nakładów na wyniki, jednak należy pamiętać, że ma on charakter względny i jest ustalany przez porównanie z innymi jednostkami). 
DEA może być oparta na założeniu stałych lub zmiennych efektów skali. Modele ze zmiennymi efektami skali pozwalają na dekompozycję efektywności na dwa składniki: czystą efektywność techniczną (pure technical efficiency) oraz efektywność skali (scale efficiency). W pracach z zakresu bankowości z reguły przyjmuje się założenie o zmiennych efektach skali, wynikające $\mathrm{z}$ faktu, że optymalna skala działania rzadko jest osiągana. Modele DEA mogą być zorientowane na nakłady (input-oriented) lub na wyniki (output-oriented). W pierwszym wypadku techniczna nieefektywność jest identyfikowana jako możliwość proporcjonalnej redukcji nakładów w celu uzyskania tego samego wyniku, w drugim zaś jako możliwość uzyskania wyższych wyników przy tym samym poziomie nakładów. W modelach z zakresu bankowości przyjmuje się najczęściej modele zorientowane na nakłady, co wynika z przekonania o większej kontroli nad nakładami niż wynikami ${ }^{14}$. W prezentowanych badaniach zastosowano model DEA zorientowany na nakłady, zakładający zmienne efekty skali.

Bardzo istotnym elementem analizy efektywności jest dobór nakładów i wyników. Zgodnie $\mathrm{z}$ dominującym $\mathrm{w}$ literaturze przedmiotu podejściem zastosowano model banku jako pośrednika, przekształcającego pozyskane fundusze w aktywa pracujące, przy wykorzystaniu zasobów ludzkich i aktywów trwałych. Model pośrednika ma jednakże wiele odmian, a dobór zestawu nakładów i wyników w sposób znaczący wpływa na uzyskane rezultaty. Ze względu na brak jednoznacznych przesłanek co do optymalnego zestawu przyjętych nakładów i wyników w badaniach wykorzystano trzy warianty modeli:

1) tradycyjny model bilansowy, w którym zdefiniowano trzy rodzaje nakładów: depozyty, wynagrodzenia oraz aktywa trwałe, a także trzy wielkości wynikowe: wartość udzielonych kredytów, inne aktywa pracujące oraz wyniki nieodsetkowe (będące odzwierciedleniem pozaodsetkowej działalności banków) - taki model wykorzystali m.in. M. Delis i in. ${ }^{15}$,

2) model przychodowy, oparty na rachunku wyników; w roli nakładów wykorzystano koszty odsetkowe i koszty pozaodsetkowe, jako wielkości wynikowe przyjęto wyniki odsetkowe i wyniki pozaodsetkowe (dobór zmiennych na podstawie modelu J.E. Sturma i B. Williamsa ${ }^{16}$ ),

3) model mieszany, w którym odzwierciedlono wzrastającą rolę depozytów jako stabilnego źródła finansowania działalności bankowej. W tym modelu depozyty

${ }_{14}$ M.D. Fethi, F. Pasiouras, Assessing bank efficiency and performance with operational research and artificial intelligence techinque: A survey, "European Journal of Operational Research" 2010, No. 204.

${ }^{15}$ M. Delis, P. Molyneux, F. Pasiouras, Regulations and productivity growth in banking: evidence from transition economies, "Journal of Money, Credit and Banking" 2011, No. 43(4).

16 J.E. Sturm i B. Williams, Foreign bank entry, deregulation and bank efficiency: Lessons from the Australian experience, "Journal of Banking and Finance" 2004, No. 28. 
przyjęto zarówno w roli nakładów (koszty odsetkowe), jak i wyników (wartość depozytów). Takie podejście zastosowali m.in. X. Chen i in. ${ }^{17}$. Drugim nakładem były koszty pozaodsetkowe, natomiast pozostałe wyniki to aktywa pracujące oraz wyniki pozaodsetkowe.

Ocenę efektywności ustalono na podstawie odległości od granicy, wyznaczonej wspólnie dla wszystkich krajów.

Tabela 2. Model bilansowy DEA: wyniki dla krajów ESW-11

\begin{tabular}{|l|c|c|c|c|c||c|c|c|c|c|}
\hline \multicolumn{1}{|c||}{ Efektywność techniczna } & \multicolumn{7}{c|}{ Efektywność skali } \\
\hline \multicolumn{1}{|c|}{ Gryterium: wielkość absolutna banku (suma aktywów) } \\
\hline Banki duże & $\mathbf{2 0 0 4}$ & $\mathbf{2 0 0 7}$ & $\mathbf{2 0 0 8}$ & $\mathbf{2 0 1 1}$ & $\mathbf{2 0 1 3}$ & $\mathbf{2 0 0 4}$ & $\mathbf{2 0 0 7}$ & $\mathbf{2 0 0 8}$ & $\mathbf{2 0 1 1}$ & $\mathbf{2 0 1 3}$ \\
\hline Banki średnie & 0,966 & 0,892 & 0,841 & 0,782 & 0,821 & 0,620 & 0,713 & 0,726 & 0,507 & 0,714 \\
\hline Banki małe & 0,676 & 0,681 & 0,613 & 0,568 & 0,619 & 0,830 & 0,958 & 0,975 & 0,777 & 0,928 \\
\hline Banki b. małe & 0,672 & 0,627 & 0,518 & 0,551 & 0,680 & 0,960 & 0,962 & 0,942 & 0,903 & 0,965 \\
\hline Kryterium: wielkość względna banku (udział rynkowy) & 0,590 & 0,559 & 0,628 & 0,866 & 0,841 & 0,734 & 0,788 & 0,833 \\
\hline Banki duże & 0,867 & 0,798 & 0,724 & 0,656 & 0,735 & 0,651 & 0,820 & 0,830 & 0,604 & 0,777 \\
\hline Banki średnie & 0,697 & 0,657 & 0,608 & 0,599 & 0,661 & 0,846 & 0,941 & 0,922 & 0,706 & 0,914 \\
\hline Banki małe & 0,649 & 0,695 & 0,643 & 0,607 & 0,674 & 0,888 & 0,948 & 0,940 & 0,835 & 0,951 \\
\hline Banki b. małe & 0,715 & 0,640 & 0,593 & 0,586 & 0,643 & 0,891 & 0,884 & 0,815 & 0,828 & 0,879 \\
\hline
\end{tabular}

Źródło: Opracowanie własne.

Tabela 3. Model przychodowy DEA: wyniki dla krajów ESW-11

\begin{tabular}{|l|c|c|c|c|c||c|c|c|c|c|c|}
\hline \multicolumn{7}{|c||}{ Efektywność techniczna } & \multicolumn{7}{c|}{ Efektywność skali } \\
\hline \multicolumn{1}{|c|}{ Kryterium: wielkość absolutna banku (suma aktywów) } \\
\hline \multicolumn{1}{|c|}{ GRUPA } & $\mathbf{2 0 0 4}$ & $\mathbf{2 0 0 7}$ & $\mathbf{2 0 0 8}$ & $\mathbf{2 0 1 1}$ & $\mathbf{2 0 1 3}$ & $\mathbf{2 0 0 4}$ & $\mathbf{2 0 0 7}$ & $\mathbf{2 0 0 8}$ & $\mathbf{2 0 1 1}$ & $\mathbf{2 0 1 3}$ \\
\hline Banki duże & 0,869 & 0,835 & 0,808 & 0,714 & 0,746 & 0,582 & 0,600 & 0,742 & 0,781 & 0,820 \\
\hline Banki średnie & 0,642 & 0,563 & 0,581 & 0,537 & 0,518 & 0,746 & 0,872 & 0,914 & 0,908 & 0,973 \\
\hline Banki małe & 0,565 & 0,501 & 0,503 & 0,473 & 0,581 & 0,904 & 0,888 & 0,955 & 0,899 & 0,872 \\
\hline Banki b. małe & 0,614 & 0,550 & 0,557 & 0,574 & 0,585 & 0,872 & 0,742 & 0,831 & 0,746 & 0,658 \\
\hline Kryterium: wielkość względna banku (udział rynkowy) & & & & & & \\
\hline Banki duże & 0,806 & 0,712 & 0,719 & 0,643 & 0,690 & 0,651 & 0,710 & 0,787 & 0,840 & 0,874 \\
\hline Banki średnie & 0,681 & 0,551 & 0,606 & 0,571 & 0,567 & 0,787 & 0,861 & 0,912 & 0,857 & 0,931 \\
\hline Banki małe & 0,563 & 0,592 & 0,549 & 0,530 & 0,536 & 0,800 & 0,826 & 0,925 & 0,894 & 0,911 \\
\hline Banki b. małe & 0,599 & 0,540 & 0,546 & 0,542 & 0,557 & 0,858 & 0,810 & 0,880 & 0,800 & 0,751 \\
\hline
\end{tabular}

Źródło: Opracowanie własne.

17 X. Chen, M. Skully, K. Brown, Banking efficiency in China: Application of DEA to pre-and post-deregulation eras: 1993-2000, “China Economic Review” 2005, No. 16. 
Tabela 4. Model mieszany DEA: wyniki dla krajów ESW-11

\begin{tabular}{|l|c|c|c|c|c||c|c|c|c|c|}
\hline \multicolumn{1}{|c||}{ Efektywność techniczna } & \multicolumn{7}{c|}{ Efektywność skali } \\
\hline \multicolumn{1}{|c|}{ GRUPA } & $\mathbf{2 0 0 4}$ & $\mathbf{2 0 0 7}$ & $\mathbf{2 0 0 8}$ & $\mathbf{2 0 1 1}$ & $\mathbf{2 0 1 3}$ & $\mathbf{2 0 0 4}$ & $\mathbf{2 0 0 7}$ & $\mathbf{2 0 0 8}$ & $\mathbf{2 0 1 1}$ & $\mathbf{2 0 1 3}$ \\
\hline Banki duże & 0,850 & 0,824 & 0,829 & 0,765 & 0,734 & 0,416 & 0,716 & 0,801 & 0,471 & 0,632 \\
\hline Banki średnie & 0,708 & 0,702 & 0,644 & 0,580 & 0,504 & 0,519 & 0,868 & 0,958 & 0,673 & 0,878 \\
\hline Banki małe & 0,563 & 0,610 & 0,553 & 0,485 & 0,530 & 0,730 & 0,945 & 0,980 & 0,766 & 0,913 \\
\hline Banki b. małe & 0,483 & 0,592 & 0,600 & 0,454 & 0,491 & 0,809 & 0,830 & 0,865 & 0,701 & 0,644 \\
\hline Kryterium: wielkość względna banku (udział rynkowy) \\
\hline Banki duże & 0,808 & 0,758 & 0,723 & 0,689 & 0,666 & 0,436 & 0,768 & 0,856 & 0,538 & 0,712 \\
\hline Banki średnie & 0,695 & 0,687 & 0,679 & 0,641 & 0,568 & 0,566 & 0,876 & 0,938 & 0,622 & 0,848 \\
\hline Banki małe & 0,561 & 0,701 & 0,637 & 0,543 & 0,511 & 0,605 & 0,911 & 0,977 & 0,740 & 0,898 \\
\hline Banki b. małe & 0,536 & 0,612 & 0,600 & 0,460 & 0,475 & 0,765 & 0,865 & 0,904 & 0,719 & 0,744 \\
\hline
\end{tabular}

Źródło: Opracowanie własne.

\section{Wyniki badań}

Przyjęta metoda badań zakładała sześciokrotne zastosowanie modelu DEA (trzy modele, dwa mierniki wielkości banku) dla każdego z analizowanych lat. Ponieważ okres przyjęty do analizy charakteryzował się wyjątkowo silną zmiennością, niepozwalającą na uśrednianie i uogólnianie uzyskanych rezultatów, wyróżniono w ramach okresu badawczego trzy podokresy: okres dynamicznego wzrostu i bardzo intensywnej działalności kredytowej (lata 2004-2007), okres kryzysu finansowego (20082010) oraz okres pokryzysowych zmian (2011-2013). Ponieważ kryzys finansowy dotknął kraje Europy Środkowo-Wschodniej w różnym czasie i z różną intensywnością, dlatego przyjęte granice, ustalone na podstawie analizy trendów czasowych w zbiorze badawczym, mają charakter umowny. Ze względu na ograniczenia objętości, $\mathrm{w}$ artykule przedstawiono wyniki tylko dla wybranych, granicznych lat: 2004, 2007, 2008, 2011 i 2013 (tabele 2, 3 i 4).

We wszystkich modelach i we wszystkich latach grupa banków dużych wyraźnie wyróżniała się najwyższą efektywnością techniczną, przy czym dystans do pozostałych grup był większy, gdy jako kryterium podziału przyjęto wielkość absolutną. Równocześnie jednak efektywność techniczna dużych banków miała tendencję malejącą ( $w$ modelach bilansowym i przychodowym zahamowaną w roku 2011, w modelu mieszanym kontynuowaną do końca okresu badawczego). Pozostałe trzy grupy wykazywały zbliżony do siebie poziom efektywności technicznej, przy czym 
spadek efektywności w czasie był znacznie mniejszy niż w wypadku banków dużych. Najniższy poziom efektywności technicznej można było zauważyć w bankach bardzo małych, gdy wielkość banku mierzona była udziałem rynkowym, natomiast w wypadku wielkości absolutnej banki małe wykazywały z reguły efektywność techniczną na niższym poziomie niż banki bardzo małe.

Odmienny obraz przedstawia analiza efektywności skali: najwyższą efektywność skali wykazały banki średnie i małe. Duże banki działały z reguły w obszarze malejącej efektywności skali, a poziom nieefektywności był większy, jeżeli wielkość banku zdefiniowano na podstawie wielkości absolutnej. W zakresie efektywności skali trudno wskazać wyraźne tendencje czasowe, $\mathrm{z}$ wyjątkiem modelu przychodowego, w którym duże banki stopniowo zmniejszały nieefektywność skali. Również wysoką nieefektywność skali (chociaż mniejszą niż banki duże) wykazywały banki bardzo małe, które z kolei często działały w obszarze rosnącej efektywności skali.

Powyższe obserwacje pozwalają pozytywnie zweryfikować hipotezę badawczą, że w krajach ESW wielkość banku ma wpływ na poziom efektywności, szczególnie jeżeli wielkość banku jest definiowana w ujęciu absolutnym. Wielkość banku ma dodatni wpływ na poziom efektywności technicznej (szczególnie po przekroczeniu pewnego progu wielkości), jednakże związek między wielkością banku i efektywnością skali ma charakter nieliniowy (niska efektywność skali banków największych i najmniejszych). Największe banki, mimo iż wartość ich aktywów w porównaniu do banków z krajów EU-15 jest niewielka, wykazują nieefektywność skali, gdyż w przeciwieństwie do nich prowadzą działalność głównie na rynku krajowym.

Najwyższą efektywność całkowitą, będącą wypadkową efektywności technicznej i efektywności skali, uzyskały banki średnie i - w zależności od modelu - banki duże lub małe, natomiast bez względu na przyjęty model najniższą efektywność całkowitą $\mathrm{w}$ analizowanym okresie wykazały banki bardzo małe. W modelu bilansowym najwyższą efektywność uzyskały banki średnie (wielkość mierzona aktywami), które równocześnie zaklasyfikowane zostały jako banki posiadające mały udział rynkowy (banki średnie działające $\mathrm{w}$ większych krajach). Równocześnie wszystkie grupy wielkościowe wykazywały podobne tendencje: niewielki wzrost efektywności w okresie 2004-2008, silny spadek w okresie 2007-2011 i powrót do tendencji wzrostowych w okresie 2011-2013. Z kolei w modelu przychodowym najwyższą efektywność całkowitą uzyskały banki duże, zarówno w ujęciu absolutnym, jak i względnym. W tym modelu bardzo wyraźnie zaznacza się wpływ skali działania banku na poziom efektywności: im większy bank, tym wyższa efektywność w przekształcaniu kosztów w wyniki. W modelu mieszanym poziom efektywności wyróżnionych grup jest podobny, z wyjątkiem grupy banków najmniejszych, które uzyskały najniższą efektywność. W modelu tym poziom efektywności (wszystkich 
grup) jest najbardziej zmienny w czasie: po silnym wzroście efektywności w okresie przedkryzysowym nastąił gwałtowny jej spadek w okresie kryzysu i powolny wzrost po roku 2011.

\section{Rysunek 1. Całkowita efektywność techniczna banków z krajów ESW}

a) model bilansowy, wielkość absolutna

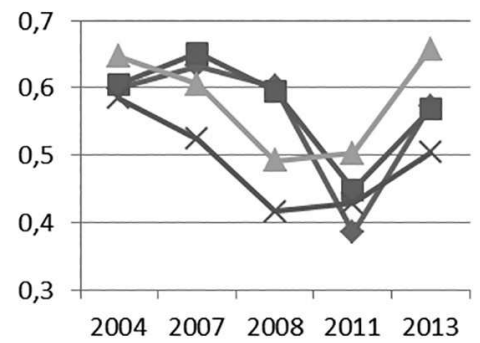

c) model przychodowy, wielkość absolutna

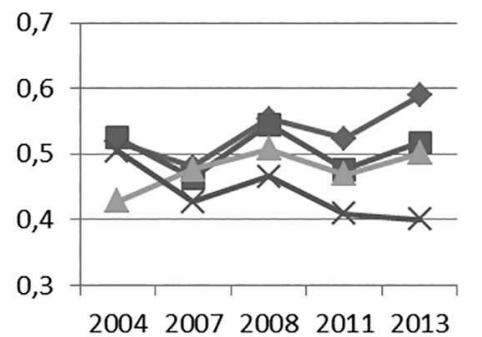

e) model mieszany, wielkość absolutna

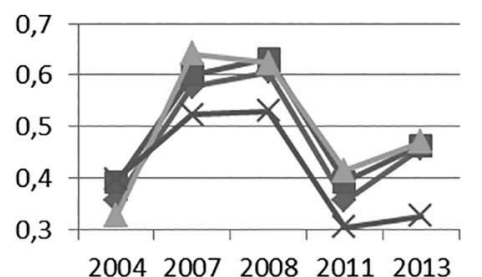

b) model bilansowy, wielkość względna

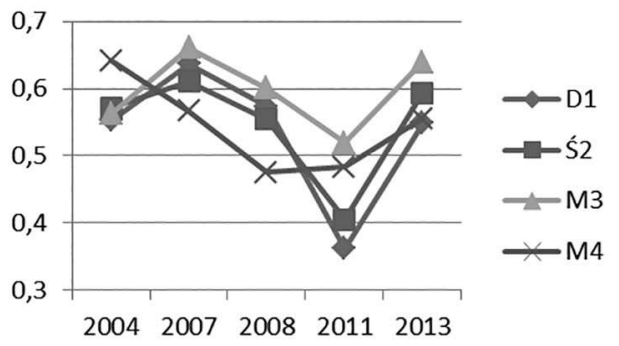

d) model przychodowy, wielkość względna

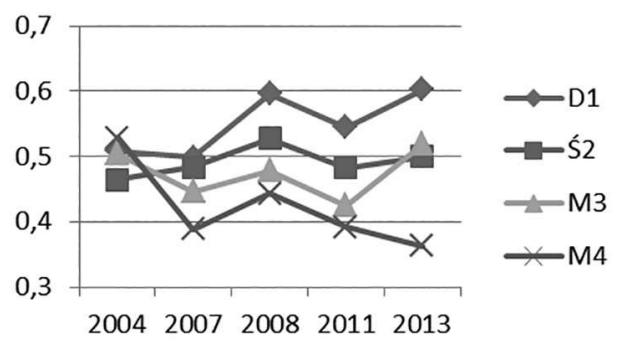

f) model mieszany, wielkość względna

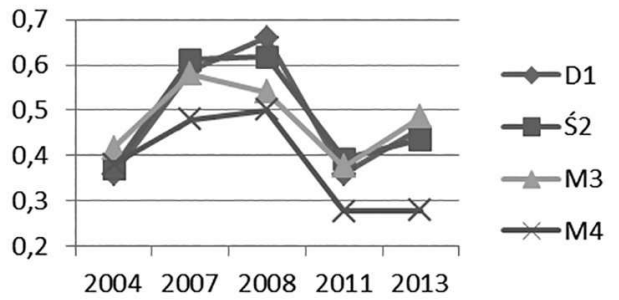

Uwaga: symbol D1 oznacza banki duże, Ś2 banki średnie, M3 banki małe, M4 banki bardzo małe. Źródło: Opracowanie własne.

W ostatnim etapie zbadano wpływ wielkości banku na jego efektywność, ograniczając analizę tylko do jednego kraju, Polski. Na rysunku 2 przedstawiono wyniki uzyskane dla modelu bilansowego (zbliżone wyniki uzyskano w pozostałych modelach). Były one podobne jak w wypadku pełnego zbioru, jeżeli jako kryterium podziału przyjęto wielkość absolutną. W sytuacji odwołania się do wielkości względnej, można 
zauważyć dodatni wpływ wielkości banku na efektywność techniczną (z wyjątkiem banków bardzo małych, które od 2008 r. uzyskały wyższą efektywność techniczną od banków małych) i ujemny wpływ na efektywność skali.

\section{Rysunek 2. Wskaźniki efektywności dla banków polskich}

a) efektywność techniczna, wielkość absolutna

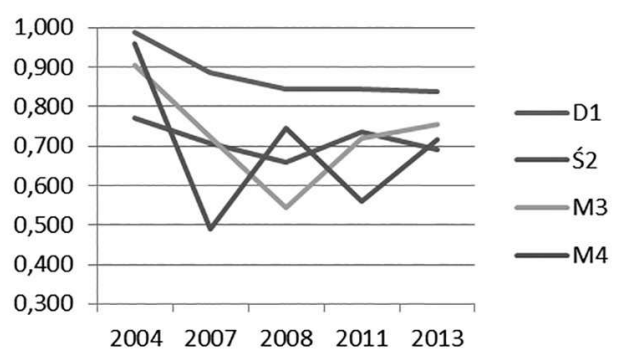

c) efektywność techniczna, wielkość względna

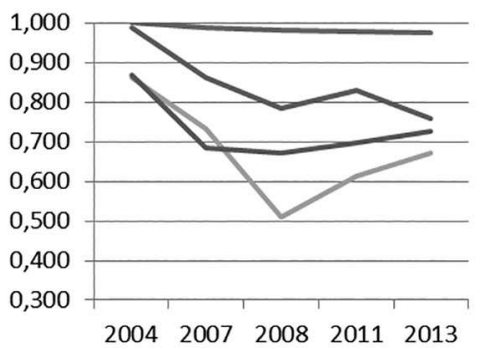

Źródło: Opracowanie własne. b) efektywność skali, wielkość absolutna

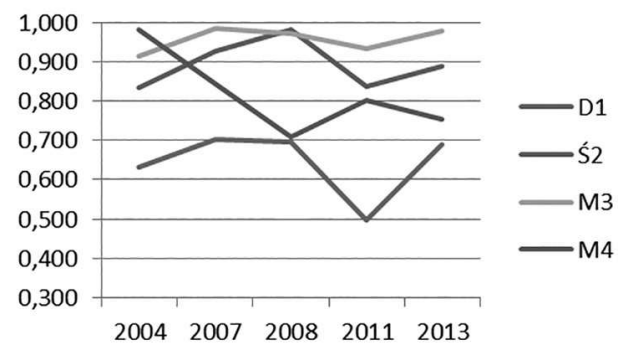

d) efektywność skali, wielkość względna

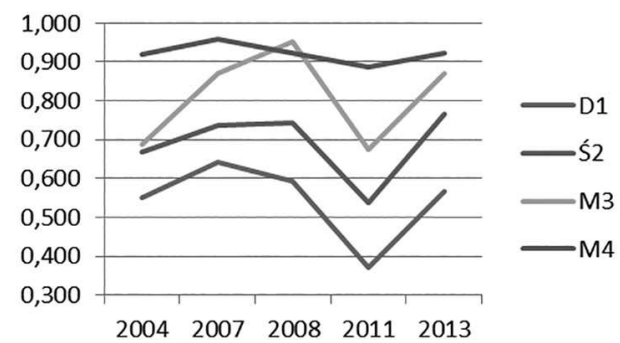

\section{Podsumowanie}

Przeprowadzona analiza empiryczna dla banków z krajów ESW potwierdza relację między wielkością banku a poziomem jego efektywności, chociaż wnioski uzależnione są od przyjętego modelu (sposobu zdefiniowania nakładów i wyników). Wielkość banku jest z reguły czynnikiem zwiększającym efektywność techniczną, ale równocześnie może stanowić źródło nieefektywności skali. Najwyższą efektywność skali uzyskały banki średnie i małe, natomiast najsłabszą efektywność, bez względu na przyjęty model, banki bardzo małe. Niska efektywność najmniejszych banków wynika często $\mathrm{z}$ działania $\mathrm{w}$ niszach rynkowych i oferowania bardziej zindywidualizowanych produktów, co znajduje odzwierciedlenie w wyższej marży odsetkowej 
i porównywalnym z bankami średnimi (a wyższym niż w małych bankach) poziomie rentowności ${ }^{18}$.

\section{Bibliografia}

Barrel R., Davis E.P., Fic T., Karim D., The future of financial regulation - Is there a link from bank size to risk?, "NIESR Discussion Paper" 2011, No. 367.

Bertay A.C., Demirgü-Kunt A., Huizinga H., Do we need big banks? Evidence on performance, strategy and market discipline, "Journal of Financial Intermediation" 2013, No. 22.

Berger A.N., Goulding W., Rice T., Do small business still prefer community banks?, "Journal of Banking and Finance" 2014, No. 44.

Carter D.A., McNulty J.E., Deregulation, technological change, and the business-lending performance of large and small banks, "Journal of Banking and Finance" 2005, No. 29.

Chen X., Skully M., Brown K., Banking efficiency in China: Application of DEA to pre- and post-deregulation eras: 1993-2000, "China Economic Review" 2005, No. 16.

De Jonghe O., Diepstraten M., Schepens G., Banks' size, scope and systemic risk: What role for conflicts of interest?, "Journal of Banking and Finance" 2015.

Delis M., Molyneux P., Pasiouras F., Regulations and productivity growth in banking: evidence from transition economies, "Journal of Money, Credit and Banking" 2011, No. 43(4).

DeYoung R., Hunter W.C., Udell G.F., Past, present, and probable future for community banks: Evidence from a degree of total leverage model, "Journal of Financial Intermediation" 2001, No. 10.

Fethi M.D., Pasiouras F., Assessing bank efficiency and performance with operational research and artificial intelligence techinque: A survey, „European Journal of Operational Research" 2010, No. 204.

De Haan J., Poghosyan T., Size and earnings volatility of US bank holding companies, "Journal of Banking and Finance" 2012, No. 36.

Hannan T.H., Prager R.A., The profitability of small single-market banks in an era of multi-market banking, "Journal of Banking and Finance" 2009, No. 33.

Mercieca S., Schaeck K., Wolfe S., Small European banks: Benefits from diversification?, "Journal of Banking and Finance" 2007, No. 31.

Stiroh K.J., Diversification in banking: is non-interest income the answer?, "Journal of Money, Credit and Banking" 2004, No. 36.

\footnotetext{
$18 \mathrm{~W}$ badaniach dokonano także analizy porównawczej podstawowych wskaźników finansowych dla wyróżnionych grup, jednak ze względu na ograniczenia objętości nie zostały one przedstawione w tekście.
} 
Sturm J.E., Williams B., Foreign bank entry, deregulation and bank efficiency: Lessons from the Australian experience, "Journal of Banking and Finance" 2004, No. 28.

Top 1000 world banks, "The Banker” 2014.

Vallascas F., Keasey K., Bank resilience to systemic shocks and the stability of banking systems: Small is beautiful, "Journal of International Money and Finance" 2012, No. 31.

\section{The Impact of Bank Size on its Efficiency: Analysis of Central and East European Countries}

Although there is a growing body of literature on the impact of bank size on its strategy, efficiency, profitability and stability, the results are still inconclusive. The main advantages of large banks are their capability for product and geographical diversification, ability to bear the cost of technological changes and easier access to financial resources. On the other hand, small banks have a good understanding of local markets, use soft information on their clients more effectively, are based on relationship banking model, and have much simpler organizational structure. The aim of this paper is to analyze the impact of bank size on its efficiency in Central and East European countries. For that purpose, all commercial banks from CEE countries were divided into four groups, depending on their size (expressed in absolute and relative terms). Technical and scale efficiency scores for the period 2004-2013 were calculated using Data Envelopment Analysis. The main conclusion is that in CEE countries bank size affects the efficiency, particularly if the size is expressed in absolute terms. There is a positive relationship between bank size and its technical efficiency (especially above a certain limit). The relationship between bank size and scale efficiency is nonlinear: the smallest and the largest banks have higher scale inefficiency.

Keywords: banks size, efficiency, DEA, Central and Eastern Europe

\section{L'influence de la taille de la banque sur son efficacité: I'analyse des pays de l'Europe centrale et orientale}

Bien que le problème de l'impact de l'échelle des opérations de la banque sur sa stratégie, son efficacité, sa rentabilité et sa stabilité soit souvent discuté dans la littérature, cependant, les conclusions formulées sont ambiguës. Parmi les arguments les plus importants en faveur de grandes banques, il y a la possibilité de 
la diversification des produits et celle géographique, la capacité de supporter des coûts fixes (y compris les coûts associés aux changements technologiques), ou un meilleur accès au financement. D'autre part, les avantages de petites banques sont le résultat de la connaissance du marché local, la possibilité d'utiliser "l'information soft" sur les clients, le modèle de banque de relation et une structure organisationnelle plus simple. Le but de cet article est une analyse empirique de l'impact de l'échelle des activités des banques dans les pays de l'Europe centrale et orientale sur leur efficacité. Les banques ont été divisées en groupes selon leur taille (absolue et relative). Ensuite les indicateurs de l'efficacité technique et de l'efficacité à grande echelle ont été comparés parmi ces groups. Les résultats pour la période 2004-2013 ont été calculés en utilisant Data Envelopment Analysis. La principale conclusion est que dans les PECO, la taille de la banque affecte son efficacité, en particulier lorsque cette taille est exprimée en termes absolus. Il existe une relation positive entre la taille de la banque et son efficacité technique. La relation entre la taille de la banque et son efficacité à grande échelle est non linéaire (une faible efficacité des plus petites et des plus grandes banques).

Mots-clés: la taille de la banque, l'efficacité, DEA, l'Europe centrale et orientale

\section{Влияние размера банка на его эффективность. Исследование стран Центральной и Восточной Европы}

Несмотря на то, что растет количество литературы относительно влияния размера банка на его стратегию, эффективность, рентабельность и стабильность, остается много вопросов. Основными преимуществами крупных банков являются их продуктовая и географическая диверсификация, способность нести затраты на технологические изменения и лучший доступ к финансовым ресурсам. С другой стороны, у небольших банков обширное знание местных рынков, более эффективное использование мягкой информации о своих клиентах, ведение банковских операций на условиях доверительных партнерских отношений с клиентом и гораздо более простая организационная структура. Целью данной работы является анализ влияния размера банка на его эффективность в странах Центральной и Восточной Европы. Для этого все коммерческие банки стран Центральной и Восточной Европы были разделены на четыре группы в зависимости от их размера (в абсолютном и относительном выражении). При использовании Data Envelopment Analysis были определены показатели технической эффективности и эффективности масштаба в 2004-2013 гг. Главным результатом 
является вывод о том, что размер банков в странах Центральной и Восточной Европы влияет на их эффективность, особенно, если размер определяется в абсолютном выражении. Существует положительная взаимосвязь между размером банка и его технической эффективностью (особенно выше определенного предела). Взаимосвязь между размером банка и эффективностью масштаба нелинейная: у маленьких и крупнейших банков более высокая неэффективность масштаба.

Ключевые слова: размер банка, эффективность, DEA, Центральная и Восточная Европа 